\title{
HUMAN BREAST TUMOUR CELLS VIABILITY EFFECT OF AFRICAN DIOSCOREA ROTUNDATA TUBER EXTRACTS IN MCF-7 AND MDA-MB231 CELL LINES.
}

Joy Ifunanya Odimegwu*, Ph.D.; Olukemi Abiodun Odukoya*, PhD.; Alejandro Español**, PhD.; Maria Elena Sales**, PhD.

*Department of Pharmacognosy, Faculty of Pharmacy, College of Medicine Campus, University of Lagos. NIGERIA and **Laboratory of Tumor Immunopharmacology, Center for Pharmacological and Botanical Studies (CEFYBO)-CONICET. School of Medicine. University of Buenos Aires. Argentina.

Corresponding author: Dr. Joy Ifunanya Odimegwu, PMB 12003 Idiaraba, Lagos. NIGERIA

+234 8170140519. jodimegwu@unilag.edu.ng; ORCID: 0000-0001-7398-1311

Co-author email addresses:

Prof. Olukemi Abiodun Odukoya; olukemiodukoya@yahoo.com ORCID: 0000-0002-0904-0610

Dr. Alejandro Español; aespan_1999@yahoo.com; ORCID: 0000-0001-8222-4259

Prof. Maria Elena Sales; malegazpio@yahoo.com.ar; ORCID: 0000-0001-5086-0007

Funding: University of Lagos, NIGERIA. Tertiary Education Trust Fund [TETFUND 2015]. Third World Academy of Sience-United Nations Educational, Scientific and Cultural Organization [TWAS-UNESCO] Fellowship, Centro de Estudios Farmacologico y Botanicos-Consejo Nacional de Investigaciones Científicas y Técnicas [CEFYBO-CONICET], Buenos Aires, Argentina. The funding organisations noted here played no roles in the design of the study and collection, analysis, and interpretation of data and in writing the manuscript.

Acknowledgement: We wish to thank TETFUND, TWAS-UNESCO for the research fellowship offered to Dr. JI Odimegwu, and CEFYBO-CONICET for accommodation and laboratory financial support offered to Odimegwu, JI. Also we wish to thank members of the Laboratory of Tumor Immunopharmacology; Center for Pharmacological and Botanical Studies, Francisco and Martin among others for all their help.

Ethics approval and consent to participate: Not applicable to this research work as it did not involve human subjects.

Consent for publication: Not applicable to this research work

Competing interests: The authors declare that they have no competing interests 
bioRxiv preprint doi: https://doi.org/10.1101/2020.05.08.084269; this version posted May 10, 2020. The copyright holder for this preprint (which was not certified by peer review) is the author/funder. All rights reserved. No reuse allowed without permission.

Authors' contributions: Odimegwu, JI; Carried out the laboratory work and wrote up the original draft of manuscript

Odukoya, OA; Supervised the preliminary laboratory work

Español, A. Supervised the confirmatory laboratory work and carried out the statistical analysis

Sales, ME; Conceptualised and designed the confirmatory laboratory work, contributed to editing and reviewing, corrected the final manuscript 


\title{
HUMAN BREAST TUMOUR CELLS VIABILITY EFFECT OF AFRICAN DIOSCOREA ROTUNDATA TUBER EXTRACTS IN MCF-7 AND MDA-MB231 CELL LINES.
}

\begin{abstract}
Objective: We aim to test the efficacy of edible Dioscorea species grown and consumed in Nigeria, Africa on two breast cancer cell lines; MCF-7 and MDA-MB231 derived from a luminal and a triple-negative breast cancer (TNBC) respectively and to confirm safety in non-tumour cells MCF-10A using a well established cytotoxic compound paclitaxel as a standard. Metastatic breast cancer is a prevalent cause of mortality in women around the world. Breast cancer therapies have greatly advanced in recent years, but many patients develop cancer re-occurrence and metastasis and subsequently yield to the disease because of chemoresistance.
\end{abstract}

Methods: Ethanolic extracts of Dioscorea rotundata boiled and raw (DiosB and DiosR) respectively were chemically analysed for the presence of diosgenin using HPLC and the cytotoxic activity of the extracts were tested on MCF-7, MDA-MB-231 and MCF-10A cells In vitro by MTT assay.

Results: DiosB and DiosR extracts showed a higher maximal effect on MCF-7 cells than on MDA-MB231 after $24 \mathrm{~h}$ and $48 \mathrm{~h}$ treatments $(\mathrm{p}<0.0001$ and $\mathrm{p}<0.05$ respectively). DiosR, if applied at a range between $50-70 \mathrm{~g} / \mathrm{ml}$, can be effective to reduce breast tumor cell viability without affecting non tumorigenic MCF-10A cells either at $24 \mathrm{~h}$ or at $48 \mathrm{~h}$. DiosB showed an $\mathrm{IC}_{50}$ of $38.83 \mu \mathrm{g} / \mathrm{ml}$ while DiosR showed an $\mathrm{IC}_{50}$ of $41.80 \mu \mathrm{g} / \mathrm{ml}$.

Conclusion: These results show that ethanolic extracts of Dioscorea rotundata tubers could be used effectively to treat breast cancer tumors and this is in sync with its diosgenin content as other Dioscorea species applied for similar treatments in Asia and elsewhere.

Keywords: Dioscorea rotundata; Herbal Medicine; Luminal A breast tumor; Triple-negative breast cancer; Paclitaxel; HPLC and MTT assays. 


\subsection{INTRODUCTION}

Dioscorea rotundata Poir. is a synonym of Dioscorea cayennensis subsp. rotundata (Poir.) J.Miège (1and 2) also called white yam (3 and 4) Fig. 1, A, B, C Dioscorea rotundata of the family Dioscoreaceae is a high value but an under-utilized, under-researched crop as millions of people in developing countries depend on the tubers as a source of staple food because of its high starch content and on its sales for livelihood. There is between $70 \%$ to $80 \%$ of dried matter of white yams are starch (5). About $97 \%$ of total world production and consumption of yams in general occur in Africa (6). Nigeria, in West Africa is the greatest producer of yams yielding more than $64 \%$ of the global crop total. (7).

Diverse Dioscorea species have been in use in traditional Chinese medicine; D. bulbifera has anti-tumour actions (8). Decoctions from yam leaves and tubers are used by traditional medicine to regulate women's fertility, relieving painful periods and peri- and post-menopausal symptoms (9). It is also reported that wild yams might reduce the risk of breast cancer and cardiovascular diseases in post-menopausal women (10). D. villosa and D. bulbifera are the most widely used as drugs in Asia (11) most probably because of their diosgenin content. In Africa, D. alata; greater yam and $D$. rotundata; white yam are more common and preferred for consumption than others (Mignouna et al., 2003), it is used medicinally traditionally as D.cayenensis its synonym due to its high antioxidant content against oxidative damage that could lead to cancer (4) and as D. rotundata with appreciable diosgenin content which has chemo-preventive action against chronic inflammation associated with cancer cells (3). Yams, like other plants can synthesize and accumulate a great deal of phytochemicals in their roots, leaves and vines as a part of its overall defence strategy against pests and diseases in vegetable kingdom. These phytochemicals are known to be useful in human illness. In previously reported research work on yam's phytochemicals, it has been proved that tubers contain a glycosidic form of steroidal saponin/sapogenin which can be cleaved by acidification into the sugar moiety and diosgenin. Steroidal extracts from D. villosa, D. floribunda and D. deltoidea are used to derive sapogenin and diosgenin used by pharmaceutical companies in the manufacture of cortisone, and other steroids (12). Edible Dioscorea species; D. rotundata have not been studied for their phytochemical contents and medicinal values which could be immense and impactful (13, 14 and 15). Steroidal saponins are less widely distributed in the plant kingdom, compared to terpenoids, although their chemical structures have been useful for the development of pharmaceuticals with steroidal activities such as diosgenin from yam. Steroidal saponin-containing plants have therefore been of greater interest for use as phytopharmaceuticals, rather than as nutraceuticals (16). 
Gynaecological malignancies are one of the leading causes of death worldwide in women. Epidemiologically, breast cancer is the most frequent type of tumor in women in both developed and developing countries. The incidence of breast cancer is increasing in the developing world due to increased life expectancy, increased urbanization and the adoption of Western lifestyles. Traditional chemotherapy has been partially useful to treat breast cancer patients because, although it can reduce tumor growth, concomitantly with undesirable effects and chemoresistance. Development of new treatment strategies that reduce costs and adverse effects are recommendable; for these reasons natural products, with demonstrated anti-tumor actions appear as a better treatment alternative. Like most epithelial tumors, breast cancer is a complex disease due to intra-tumor and inter-tumor heterogeneity. Breast tumors can be classified into 4 groups according to their genetic profile: Luminal A, express estrogen receptor (ER)+, Luminal B are ER+ and/or progesterone receptor (PR)+, and HER2+ or HER2-; and Basal (or triple negative) (ER- / PR- / HER2-). The survival of patients, after 5 years, decreases significantly from [1] to [4]. The decreasing percentage of survival is related to increased resistance to chemotherapy and/or radiotherapy and to a greater likelihood of relapse and/or metastasis formation. MCF-7 and MDA-MB231 cells represent the two extremes of this classification. MCF-7 cells derived from a human breast luminal A adenocarcinoma while MDA-MB231 cell line was obtained from a highly aggressive, invasive and poorly differentiated triple-negative breast cancer (TNBC) (17).

The purpose of this research is to carry out phytochemical assays on edible D. rotundata and to analyze the anti-tumour actions of two different extracts on human breast tumor cells and to compare them with the conventional chemotherapeutic agent paclitaxel. 


\subsection{METHODOLOGY}

\subsection{Plant materials}

The tubers of Dioscorea species were obtained from International Institute of Tropical Agriculture, IITA Ibadan, D. rotundata (TDR 3731) and from a vendor at Ojuwoye market of Mushin Local Government Area, Lagos State. Nigeria.

\subsection{Preparation of $D$. rotundata samples}

The tubers were peeled, cut up into minisettes and washed. A portion of minisettes were boiled (DiosB) in clean water in an aluminium pot for 15 minutes and then strained and dried while the other half was also peeled, washed and cut into raw minisettes (DiosR). They were air dried during $72 \mathrm{~h}$ and then oven dried at $60^{\circ} \mathrm{C}$ for 15 min then milled into coarsely powdered samples and stored in glass bottles until needed.

\subsection{Extraction and Thin-layer chromatography of DiosB and DiosR extracts}

DiosB and DiosR samples each were weighed and extracted by cold maceration. The powdered samples were extracted in aqueous ethanol $(25: 75)$ by cold maceration three times and then filtered and dried in open air. The recovered dry extracts were saved at $4{ }^{\circ} \mathrm{C}$ until used. Preparative TLC was carried out on silica gel plates (Kieselgel G, F254, type 60, Merck, Germany) eluted with Chloroform, Toluene, Methanol, Ethyl acetate in 7: 2.4: 0.8: 0.4, Diosgenin was used as standard. The developed TLC plate was observed under UV at $254 \mathrm{~nm}$ and $366 \mathrm{~nm}$. Visualization was also further achieved by spraying with Distilled water in chilled acetone, 60\% Perchloric acid and Anesaldehyde in the following proportions 8:2:1:0.5 heat was applied in an oven at about $110^{\circ} \mathrm{C}$ for 3-5 min. Plates were scanned or photographed while color of spots were still visible.

\subsection{Extraction of (TDR 3731) tubers using Soxhlet apparatus}

Dried and powdered (TDR 3731) tubers were packed into the thimble and then inserted into the Soxhlet extractor. The Soxhlet was inserted into the quick fit round bottom flask containing n-hexane with temperature of 40-600 C. The obtained extracts were subjected to Thin Layer Chromatography (TLC) and Gas Chromatography-Mass Spectrometry (GC-MS). 


\subsection{GC-MS analysis of (TDR 3731) tuber hexane extracts}

A sample of TDR 3731 was injected into the Agilent technologies 7890GC-MS machine with number G3170-80026. The oven temperature program ranged from $70^{\circ} \mathrm{C}$ to $250^{\circ} \mathrm{C}$, programmed at $3^{\circ} \mathrm{C} / \mathrm{min}$, with initial and final hold time of $2 \mathrm{~min}$, carrier gas: He at 10 psi constant pressure, a split ratio of $1: 40$; injector, transfer line, and source temperatures were kept at $250^{\circ} \mathrm{C}$; ionization energy $70 \mathrm{eV}$; mass scan range 40-450 amu. Characterization was achieved on the basis of retention time, elution order, in GC-FID capillary column (Aldrich and Fluka), mass spectra library search (NIST/EPA/NIH version 2.1, and Wiley registry of mass spectral data $7^{\text {th }}$ edition).

\subsection{High Performance Liquid Chromatography Analysis of DiosB and DiosR}

For Calibration Curve and Linearity studies; The specific system used is a combination of Waters HPLC System and Agilent 1100 HPLC with a quartenary pump, an auto liquid sampler (ALS), a thermostated column compartment and a variable wavelength detector (VWD). The analysis is carried out at a constant flow rate of $1.0 \mathrm{ml} / \mathrm{min}$ all throughout. The mobile phase is a mixture of acetonitrile and water in a ratio 90:10 v/v. for diosgenin. The different components in our samples are detected by a variable wavelength UV detector set at $203 \mathrm{~nm}$ and the data station displays the recorded data in the form of chromatograms at volumes $20 \mu \mathrm{L}$. The extracts were duly prepared for HPLC. Calibration curve was obtained from the standards working solutions for linearity studies and was plotted using Microsoft Excel. Every sample, from the standards to the Dioscorea samples, were prepared and injected into the HPLC system.

\subsection{Cell culture}

The human breast adenocarcinoma cell line MDA-MB231 (CRM-HTB-26) and MCF-7 (HTB-22) were obtained from the American Type Culture Collection (ATCC; Manassas, USA) and cultured in DMEM (Invitrogen Inc., Carlsbad, USA) with $2 \mathrm{mM} \mathrm{L-glutamine} \mathrm{and} 80 \mu \mathrm{g} / \mathrm{ml}$ gentamycin, supplemented with $10 \%$ heat inactivated fetal bovine serum (FBS) (Internegocios SA, Mercedes, Argentine) at $37^{\circ} \mathrm{C}$ in a humidified $5 \% \mathrm{CO}_{2}$ air. $\mathrm{MCF}-10 \mathrm{~A}$ cells (CRL-10317) were also purchased by ATCC and constitute a non- tumorigenic cell line derived from human mammary tissue. These cells were grown on tissue culture plastic dishes in DMEM:F12(1:1) (Invitrogen Inc., Carlsbad, USA) supplemented with 10\% FBS, hydrocortisone $(0.5 \mu \mathrm{g} / \mathrm{ml})$, insulin $(10 \mu \mathrm{g} / \mathrm{ml})$, and hEGF $(20 \mathrm{ng} / \mathrm{ml})$. Cell lines were detached using the following buffer: 0.25\% trypsin and 0.02\% EDTA in Ca2+ and $\mathrm{Mg} 2+$ free PBS from confluent monolayers. The medium was replaced three times a week. Cell 
viability was assayed by Trypan blue exclusion test and the absence of mycoplasma was confirmed by Hoechst staining.

\subsection{MTT assay}

Cell viability was evaluated by a colorimetric assay using the reagent 3- (4,5-dimethylthiazol-2-yl) -2,5-diphenyl tetrazolium bromide (MTT) Cells were seeded in 96-well plates $\left(10^{4}\right.$ cells/well) in 200 $\mu \mathrm{l}$ of DMEM culture medium supplemented with $5 \%$ of FBS at $37^{\circ} \mathrm{C}$ in a humidified atmosphere with $5 \% \mathrm{CO}_{2}$. The cells were deprived of FBS for $24 \mathrm{~h}$ and then treated with increasing concentrations of DiosB, DiosR, diosgenin and paclitaxel (the latter 2 were used as controls to induce cell death) added during $24 \mathrm{~h}$ or $48 \mathrm{~h}$. After treatment, medium was replaced by fresh DMEM medium without phenol red, and MTT solution ( $0.5 \%$ in PBS) was added. Finally the absorbance at $540 \mathrm{~nm}$ was measured in an ELISA reader computerized with the Gen5 program and the cell viability was calculated as a percentage with respect to the control (untreated cells considered as $100 \%)$.

\subsection{RESULTS AND DISCUSSION}

Fig 1. A. Boiled minisettes of white yam (DiosB). B. Raw minisettes of white yam (DiosR) C. White yam tubers on display at a market. D. Ethanolic extracts of DiosB and DiosR.

Thin layer Chromatography showed presence of diosgenin in hexane extract of TDR (3731) and ethanolic extracts of DiosB and DiosR (Fig. 1 D) confirmed by HPLC. This is very interesting considering that previous works on Dioscorea analyzing the content of diosgenin had been performed on inedible species like D. zingiberensis, D. septemloba, D. collettii (18). Kanu et al., 2018 mentioned the presence of diosgenin in white yam in an inconclusive manner as they were unable to confirm diosgenin presence with chemical analysis. The discovery of diosgenin in edible yams is huge as the tubers are staple foods to hundreds of thousands of indigenious people in Africa and particularly in Nigeria. Also Caryophylene and Pthallic acid were discovered in the hexane extracts of TDR (3731) from the GC-MS analysis (Appendix 1). 
Figure. 2 HPLC Chromatogram of diosgenin.

Figure 3: HPLC Chromatogram of DiosR showing diosgenin peak

Figure 4: Diosgenin chromatogram of DiosB showing diosgenin peak

Diosgenin is present in both DiosB and DiosR as it was confirmed by HPLC, Fig. 3 and 4. We observed that the amount of diosgenin in the boiled sample is higher than that in the raw one Figures 3 and 4 Edible Dioscorea cultivated in Africa has been never analyzed regarding diosgenin content and for this reason our findings could constitute novel and interesting knowledge for botanical medicine. Chinese species of Dioscorea; D. zingiberesis, D. oppositifolia and D. japonica have diosgenin $(18,23,25)$.

Diosgenin has already been reported to exert anti-proliferative effects on different types of cancer cells including breast tumor cells $(19,24,26)$. Here, we confirmed these actions on MDA-MB231 and MCF-7 cells obtaining concentration- dependent actions after $24 \mathrm{~h}$ and $48 \mathrm{~h}$ treatment. Unfortunately, diosgenin was also effective and similarly potent on non-tumorigenic MCF-10A cells as an undesirable action,

\footnotetext{
Figure 5: Modulation of MCF-7 breast tumor cell viability. Concentration-response curves of $D$. rotundata extracts boiled (DiosB) or raw (DiosR) added at A) $24 \mathrm{~h}, \mathrm{~B}) 48 \mathrm{~h}$ and C) concentration-response curves of Diosgenin added during at $24 \mathrm{~h}$ and $48 \mathrm{~h}$. Results were expressed as percentage of change respect to control (cells without treatment considered as $100 \%$ ). Values are mean \pm S.E.M. of 4 experiments performed in quadruplicate $\left(\# \mathrm{P}<0.05\right.$; \#\# $<0.01$; \#\#\#P<0.0001 DiosB vs. DiosR. ${ }^{*} \mathrm{P}<0.05 ;{ }^{* *} \mathrm{P}<0.001 ;{ }^{* * *} \mathrm{P}<0.0001$ vs. control.
}

Figure 6: Modulation of MDA-MB231 breast tumor cell viability. Concentration-response curves of D. rotundata extracts boiled (DiosB) or raw (DiosR) added at A) $24 \mathrm{~h}, \mathrm{~B}) 48 \mathrm{~h}$ and C) concentration-response curves of Diosgenin. Results were expressed as percentage of change respect to control (cells without treatment, considered as 100\%). Values are mean \pm S.E.M. of 4 experiments

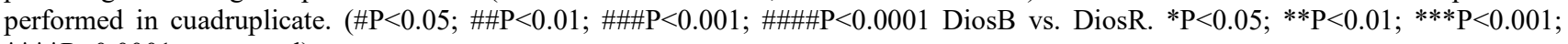
$* * * * \mathrm{P}<0.0001$ vs. control).

Here, we analyzed the action of DiosR and DiosB that contain diosgenin on tumor cells. We observed that, both extracts were effective to reduce tumor cell viability in a concentration-dependent manner but in a less potent manner than pure diosgenin. No differences were observed between both extracts and both times of treatment on MCF7 cells (Fig. 5A and B); but either DiosB or DiosR exerted a time dependent action on MDA-MB231 cells being more effective at $48 \mathrm{~h}$ than at $24 \mathrm{~h}$ (Fig 6). In spite of this, both extracts were more effective on MCF-7 than on MDA-MB231 cells showing a higher maximal effect on MCF-7 cells than on MDA-MB231 either after $24 \mathrm{~h}$ or $48 \mathrm{~h}$ of treatment $(\mathrm{p}<0.0001$ and $\mathrm{p}<0.05$ respectively) probably due to the high aggressiveness and invasiveness documented by many authors for triple negative MDA-MB231 tumor cells $(20,21)$. 
Another important finding of our work is that both extracts, but mainly DiosR were more effective on tumor cells than in non-tumor MCF-10A human breast cells (Fig. 7 and Table I). This could be taken as an advantage in comparison to traditional chemotherapy. It is important to note that if DiosR is used at a range between $50-70 \mathrm{~g} / \mathrm{ml}$ it can be effective to reduce breast tumor cell viability without affecting non tumorigenic MCF-10A cells either at $24 \mathrm{~h}$ or at $48 \mathrm{~h}$ (Fig. 5-7).

Figure 7: Modulation of MCF-10A non-tumorigenic breast cell viability. Concentration-response curves of D. rotundata extracts boiled (DiosB) and raw (DiosR) added during A) $24 \mathrm{~h}, \mathrm{~B}) 48 \mathrm{~h}$ and C) concentration-response curves of Diosgenin added during 24 and $48 \mathrm{~h}$. Results were expressed as percentage of change respect to control (cells without treatment considered as $100 \%$ ). Values are mean \pm S.E.M. of 4 experiments performed in quadruplicate. $(\# \mathrm{P}<0.01$ DiosB vs. DiosR. $* \mathrm{P}<0.05 ; * * \mathrm{P}<0.01 ; * * * \mathrm{P}<0.001$; $* * * * \mathrm{P}<0.0001$ vs. control). 
Table I. Comparison of the effect exerted by DiosR on human breast cells.

\begin{tabular}{|l|c|c|}
\hline \multirow{3}{*}{ Cell Line } & \multicolumn{2}{|c|}{$\begin{array}{c}\text { DiosR } \\
(75\end{array}$} \\
\cline { 2 - 3 } & $\begin{array}{c}\text { Time } / \mathrm{ml}) \\
(\mathrm{h})\end{array}$ & $\begin{array}{c}\text { Effect } \\
\text { \% of inhibition })\end{array}$ \\
\hline MCF-7 & 24 & $72 \pm 3^{\text {ac }}$ \\
\hline & 48 & $69 \pm 1^{\text {bd }}$ \\
\hline MDA-MB231 & 24 & $58 \pm 6^{\text {ac }}$ \\
\hline MCF-10A & 48 & $56 \pm 4^{\text {bd }}$ \\
\hline & 24 & $21 \pm 7^{\text {a }}$ \\
\hline
\end{tabular}

Cells were treated with the maximal effective concentration of DiosR $(75 \mathrm{ug} / \mathrm{ml})$ during 24 and $48 \mathrm{~h}$. Results were expressed as percentage of inhibition in cell viability with respect to control (cells without treatment considered as $100 \%$ ). Values are mean \pm S.E.M. of 4 experiments performed in quadruplicate. MCF-7 and MDA-MB231 cells vs. MCF-10A cells $24 \mathrm{~h}$ (a) $\mathrm{p}<0.0001 ; 48 \mathrm{~h}$ (b) $\mathrm{p}<0.0001$; MCF-7 cells vs. MDA-MB231cells $24 \mathrm{~h}$ (c) $\mathrm{p}<0.05$ and $48 \mathrm{~h}$ (d) $\mathrm{p}<0.05$. 
Table II. Comparison of the effect of DiosR with paclitaxel.

\begin{tabular}{|l|c|c|}
\hline \multirow{2}{*}{ Cell Line } & \multicolumn{2}{|c|}{ EC25 (48 h) } \\
\cline { 2 - 3 } & DiosR $(\mathrm{g} / \mathrm{ml})$ & Paclitaxel $(\mathrm{M})$ \\
\hline MCF-7 & 38.79 & $3.97 . \times 10^{-8} \mathrm{M}$ \\
\hline MDA-MB231 & 37.97 & $5.95 \times 10^{-8} \mathrm{M}$ \\
\hline MCF-10A & 48.73 & $4.42 \times 10^{-7} \mathrm{M}$ \\
\hline
\end{tabular}

Cells were treated at $48 \mathrm{~h}$ with increasing concentrations of both compounds and the effective concentrations necessary to reduce to $25 \%$ cell viability (EC25) was calculated. Values are mean \pm S.E.M. of 4 experiments performed in quadruplicate. 
As shown in Table II, lower concentrations of DiosR are needed to reduce the viability of tumor cells in comparison to normal cells by $25 \%$, similarly to paclitaxel, a chemotherapeutic agent obtained from the plant, Pacific yew, Taxus brevifolia frequently used to treat breast cancer patients (22), revealing a certain degree of specificity for DiosR as an anti-tumor compound.

In conclusion our work demonstrates the effectiveness of two extracts obtained from Dioscorea rotundata that are able to reduce breast tumor cells viability derived not only from a Luminal A tumor, like MCF-7 cells but also from a triple negative breast tumor, MDA-MB 231 that is considered one of the most aggressive in the molecular classification of tumors. The administration of Dioscorea rotundata instead of conventional chemotherapeutic agents like paclitaxel could be a useful and cheaper strategy and also less harmful to treat breast cancer in developing countries employing natural medicine 


\section{REFERENCES}

1. The Plant List, 2013. Version 1.1. Published on the Internet; http://www.theplantlist.org/ (accessed 20th January 2020).

2. PROTA, 2017. PROTA4U web database. Grubben G. J. H., Denton, O. A, eds. Wageningen, Netherlands: Plant Resources of Tropical Africa. http://www.prota4u.org/search.asp

3. Kanu, Ann N. Chinelo V.Ezeocha and Nwamaka P.Ogunka 2018. A Review on Bioactive Compounds of Yam Varieties for Human Disease Management Asian Food Science Journal1(4): $1-10$.

4. Ezeabara, Chinelo A and Regina O Anona. 2018. "Comparative Analyses of Phytochemical and Nutritional Compositions of Four Species of Dioscorea". Acta Scientific Nutritional Health 2.7: 90-94

5. Das A, Chaudhuri D, Mandal N, Chatterjee A., 2012. Study of antioxidant and reactive oxygen species scavenging activity of the edible tuber of "greater yam" (Dioscorea alata L.) from North-east India. Asian Journal of Pharmaceutical and Clinical Research, 5(3), , 74-84.

6. Mignouna, H. D., Abang, M. M. and Asiedu, R., 2003. Harnessing modern biotechnology for tropical tuber crop improvement: Yam (Dioscorea spp.) molecular breeding. African Journal of Biotechnology 2 (12): 478-485.

7. Food and Agricultural Organisation Statistical Data 2008.UN, FAO. Rome.

8. Wang, Jun-Ming, Li-Li Ji, Christopher J. Branford-White, Zai-Yong Wang, Kai-Kai Shen, Hai Liu, and Zheng-Tao Wang, 2012. Antitumor activity of Dioscorea bulbifera L. rhizome in vivo Fitoterapia 83: 388-394

9. Wen, H., Wu, Li,Y. Liu, Cheng, J. Chung, M.S, Hei, J. Jou and T.Wang, A., 2005. Estrogenic Effect of Yam Ingestion in Healthy Postmenopausal Women. Journal of the American College of Nutrition 24, 4: 235-243.

10. Park, M. K, Kwon, H.Y, Ahn, WS, Bae S, Rhyu, M. R, Lee, Y., 2009. Estrogen activities and the cellular effects of natural progesterone from wild yam extract in mcf-7 human breast cancer cells.Am J Chin Med. 37(1):159-67. 
11. Kumar S, Das, G., Shin H-S and Patra J. K.,2017) Dioscorea spp. (A Wild Edible Tuber): A Study on Its Ethnopharmacological Potential and Traditional Use by the Local People of Similipal Biosphere Reserve, India. Front. Pharmacol. 8:52. doi: 10.3389/fphar.2017.00052

12. Avula, B., Wang, Y. H., Wang, M., Ali, Z., Smillie, T. J., Zweigenbaum, J., \& Khan, I. A., 2014. Characterization of steroidal saponins from Dioscorea villosa and D. cayenensis using ultrahigh performance liquid chromatography/electrospray ionization quadrupole time-of-flight mass spectrometry. Planta medica, 80(4), 321-329. doi:10.1055/s-0033-1360330

13. Mazzio, Elizabeth A. and Soliman, Karam F. A., 2009. In Vitro Screening for the Tumoricidal Properties of International Medicinal Herbs Phytother Res. 23(3): 385-398. doi:10.1002/ptr.2636.

14. Asha, K. I. and Nair, M. C., 2002. Ethnic knowledge system on wild Dioscorea (yams) by the Kanikkars of Southern Western Ghats, Kerala. Indian 15:146-149.

15. Odimegwu, Joy I. , Ritesh K. Yadav, Steve O. Ogbonnia, Olukemi A. Odukoya, Neelam S. Sangwan, 2017. In vitro Diosgenin Augmentation in Microtubers of Dioscorea floribunda (M. Martens \& Galeotti) Trop J Nat Prod Res: 1(2):69-75

16. Chen Y, Vasilenko A, Song X, Valanejad L, Verma R, You S, Yan B, Shiffka S, Hargreaves, L, Nadoly C, Deng R., 2015. Estrogen and estrogen receptor- $\alpha$-mediated trans-repression of bile salt export pump. Mol Endocrinol29: 613-626.

17. María Elena Sales, 2018. Breast cancer: Metronomic Therapy Focused on Muscarinic Acetylcholine Receptors Integr Cancer Sci Therap, 5(5): 1-2

18. Yi et al., 2014. Comparative analysis of diosgenin in Dioscorea species and related medicinal plants by UPLC-DAD-MS. BMC Biochemistry 15:19.

19. Shishodia, S.; Aggarwal, B.B., 2006. Diosgenin inhibits osteoclastogenesis, invasion, and proliferation through the down regulation of Akt, I kappa B kinase activation and NF-kappa B-regulated gene expression. Oncogene, 25, 1463-1473.

20. Espinoza-Sánchez, Nancy Adriana Eduardo Vadillo, and Ezequiel M. Fuentes-Pananá. 2017. Evidence of lateral transmission of aggressive features between different types of breast cancer cells. International Journal of Oncology 51: 1482-1496. 
21. Jeonghun Han, Wanyoung Lim, Daeun $\mathrm{Yu}$, et al., 2019. "Chemoresistance in the Human Triple-Negative Breast Cancer Cell Line MDA-MB-231 Induced by Doxorubicin Gradient Is Associated with Epigenetic Alterations in Histone Deacetylase,” Journal of Oncology, 2019: 1345026, 12 . https://doi.org/10.1155/2019/1345026.

22. Holmes FA, Walters RS, Theriault RL et al. 1991. Phase II trial of Taxol, an active drug in the treatment of metastatic breast cancer. J Natl Cancer Inst. ; 83:1797-1805.

23. Jia-Fu Feng, Yi-Na Tang, Hong Ji, Zhan-Gang Xiao, Lin Zhu, and Tao Yi., 2017. Biotransformation of Dioscorea nipponica by Rat Intestinal Microflora and Cardioprotective Effects of Diosgenin. Oxidative Medicine and Cellular Longevity 4176518: 9.

24. Nigjeh, S.E., Yeap, S.K., Nordin, N., Kamalideghan, B., Ky. H., and Rosli R., 2018. Citral induced apoptosis in MDA-MB-231 spheroid cells. BMC Complement Altern Med 18, 56 doi:10.1186/s12906-018-2115-y

25. Zhu, Yuling,Wen Huang, Jinren Ni, 2010. A promising clean process for production of diosgenin from Dioscorea zingiberensis C. H. Wright Journal of Cleaner production (18) 3: 242-247

26. Zeng, MengnanLi Zhang, Miao Li, Beibei Zhang, Ning Zhou, Yingying Ke, Weisheng Feng and Xiaoke Zheng, 2018. Estrogenic Effects of the Extracts from the Chinese Yam (Dioscorea opposite Thunb.) and Its Effective Compounds In Vitro and In Vivo Molecules. 23, 11; doi: 10.3390 


\section{HUMAN BREAST TUMOUR CELLS VIABILITY EFFECT OF AFRICAN DIOSCOREA ROTUNDATA TUBER EXTRACTS IN MCF-7 AND MDA-MB231 CELL LINES.}

Joy Ifunanya Odimegwu*, Ph.D.; Olukemi Abiodun Odukoya*, PhD.; Alejandro Español**, PhD.; Maria Elena Sales**, PhD.

*Department of Pharmacognosy, Faculty of Pharmacy, College of Medicine Campus, University of Lagos. NIGERIA and **Laboratory of Tumor Immunopharmacology, Center for Pharmacological and Botanical Studies (CEFYBO)-CONICET. School of Medicine. University of Buenos Aires. Argentina.

Corresponding author: Dr. Joy Ifunanya Odimegwu, PMB 12003 Idiaraba, Lagos. NIGERIA
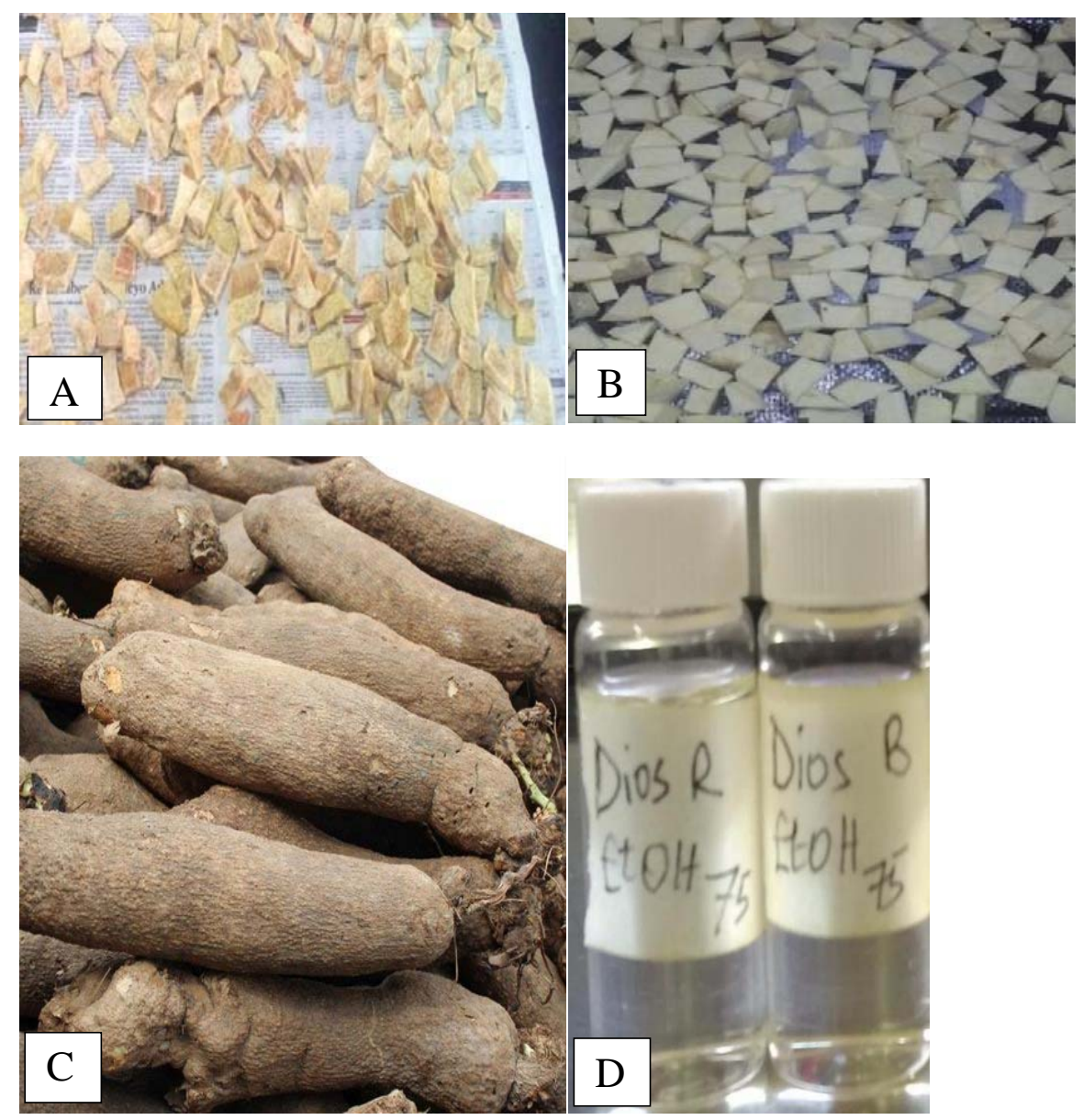

Fig I. A. Boiled minisettes of white yam (DiosB). B. Raw minisettes of white yam (DiosR) C. White yam tubers on display at a market. D. Ethanolic extracts of DiosB and DiosR. 


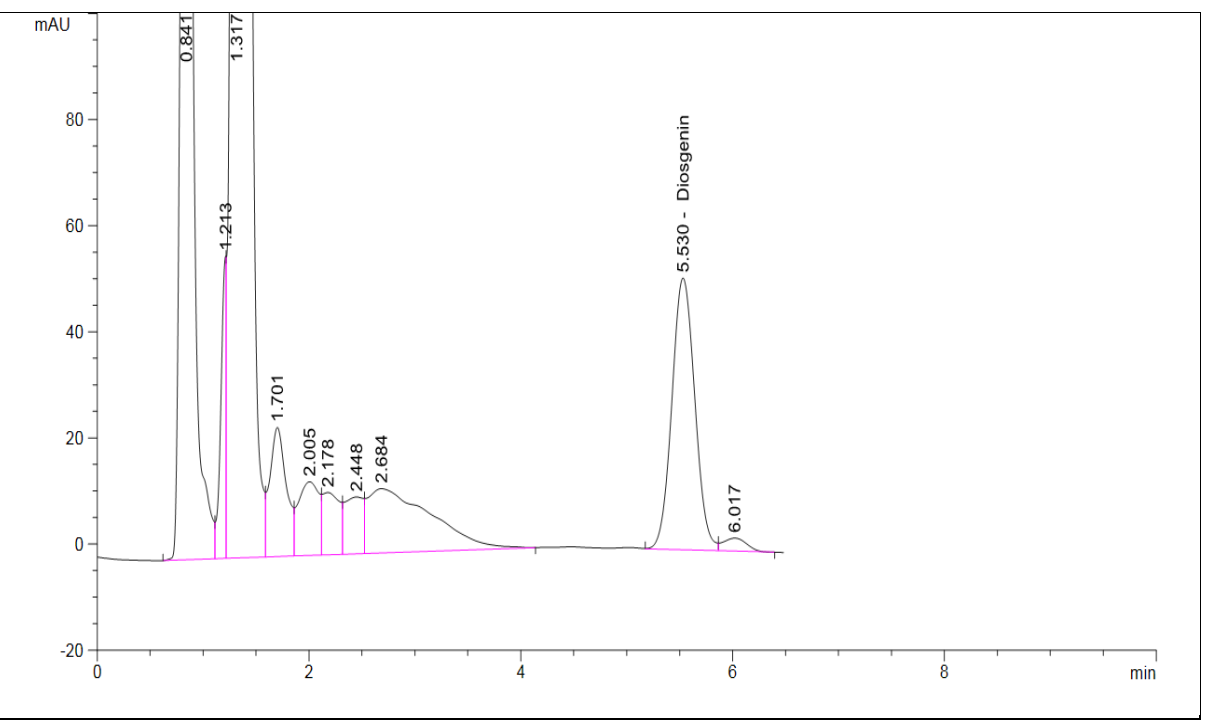

Figure. II HPLC Chromatogram of diosgenin.

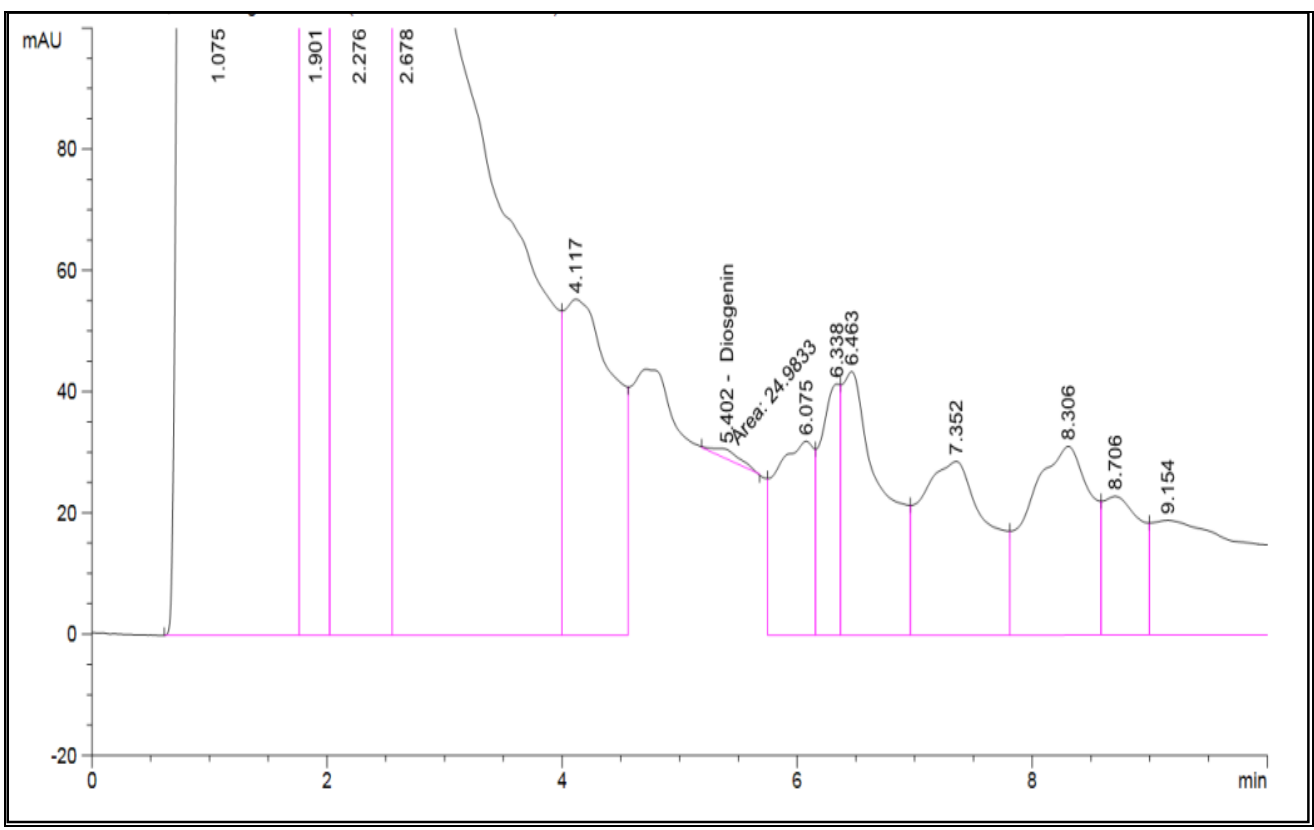

Figure III: HPLC Chromatogram of DiosR showing diosgenin peak 


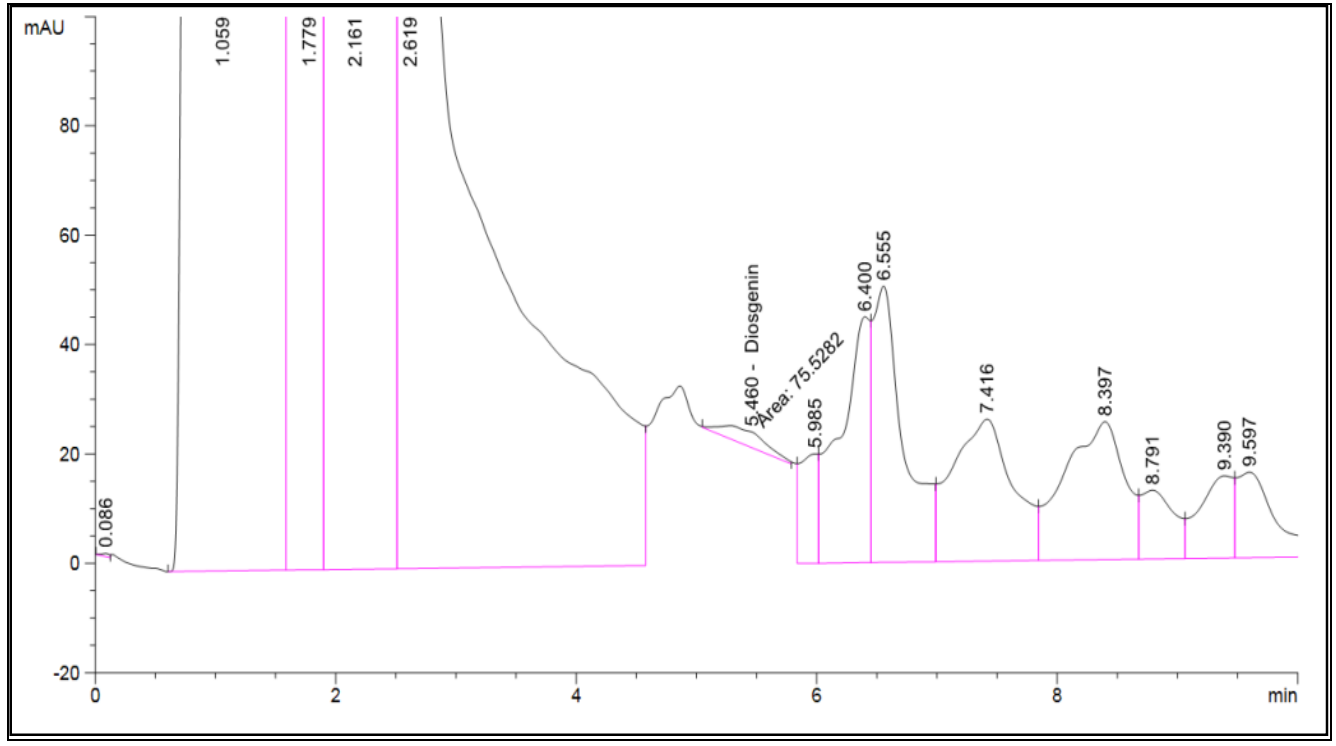

Figure IV: Diosgenin chromatogram of DiosB showing diosgenin peak 


\section{A $\quad$ MCF-7}

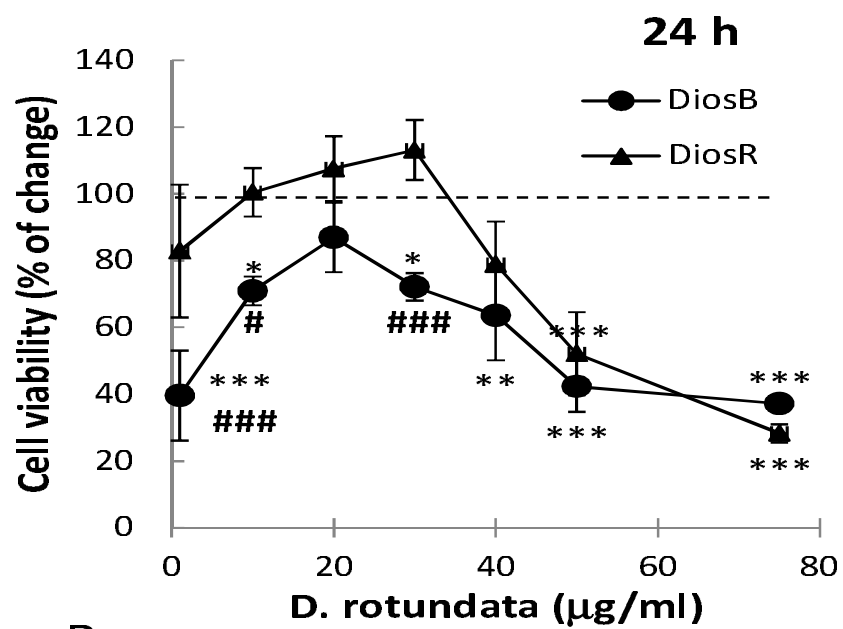

B

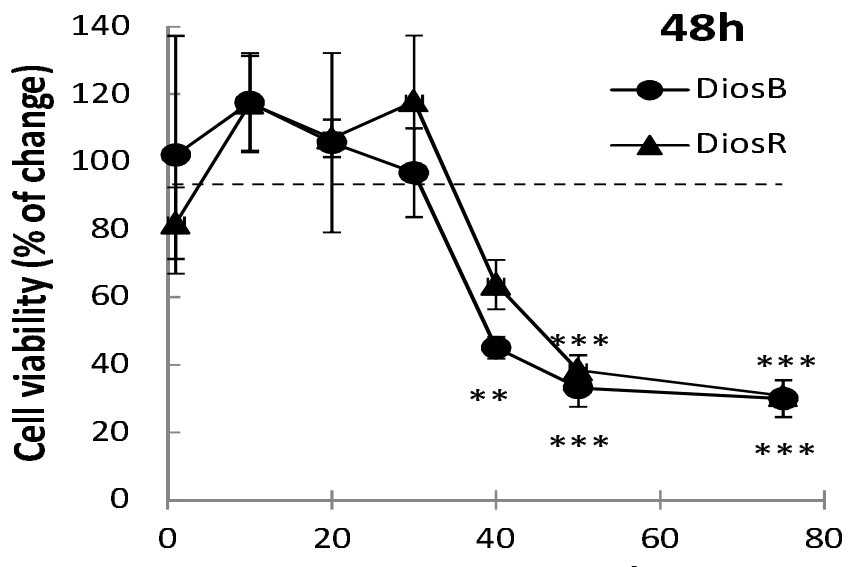

C

D. rotundata $(\mu \mathrm{g} / \mathrm{ml})$

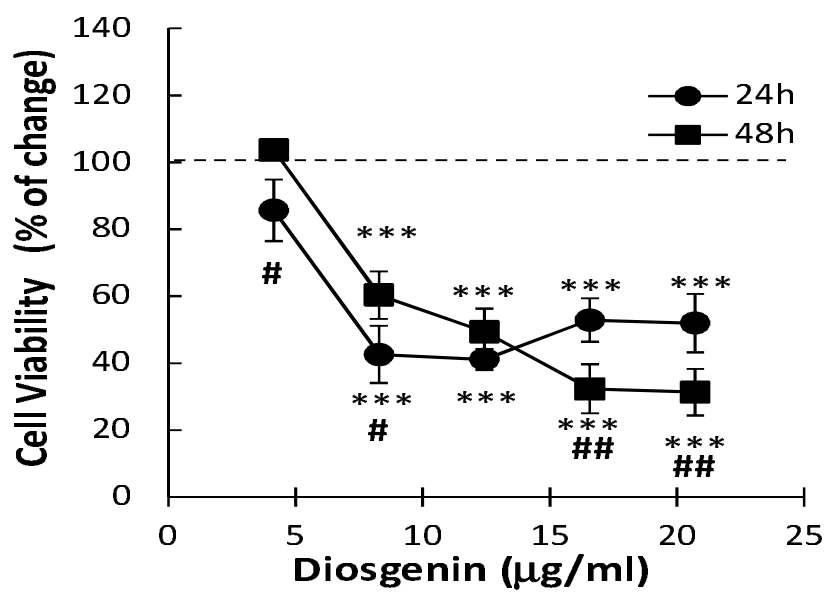

Figure V: Modulation of MCF-7 breast tumor cell viability. Concentration-response curves of $D$. rotundata extracts boiled (DiosB) or raw (DiosR) added at A) $24 \mathrm{~h}, \mathrm{~B}) 48 \mathrm{~h}$ and C) concentration-response curves of Diosgenin added during at $24 \mathrm{~h}$ and $48 \mathrm{~h}$. Results were expressed as percentage of change respect to control (cells without treatment considered as $100 \%)$. Values are mean \pm S.E.M. of 4 experiments performed in quadruplicate $(\# \mathrm{P}<0.05 ; \# \# \mathrm{P}<0.01$; \#\#\#P<0.0001 DiosB vs. DiosR. *P<0.05; **P<0.001; ***P<0.0001 vs. control. 


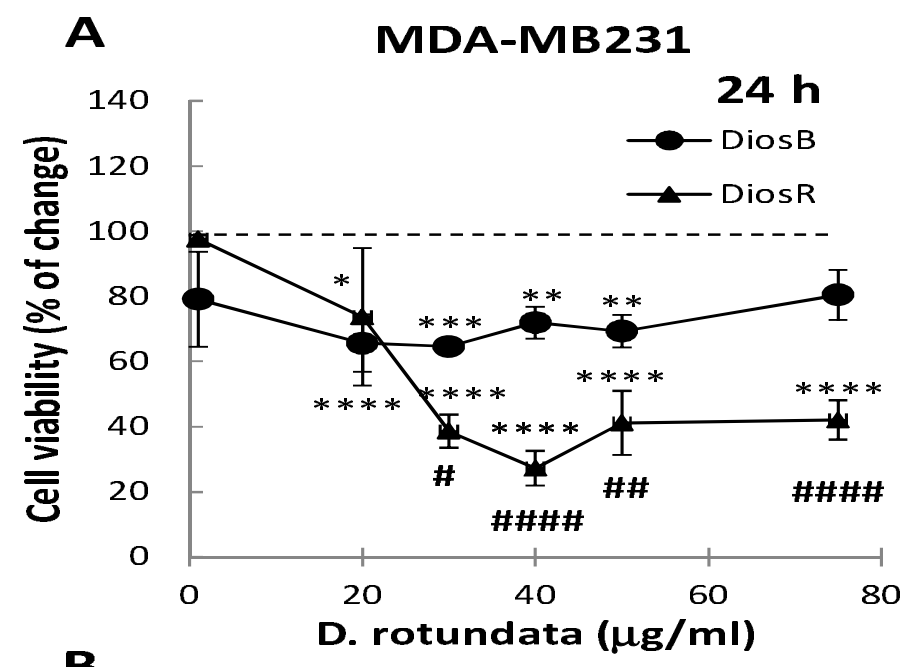

B

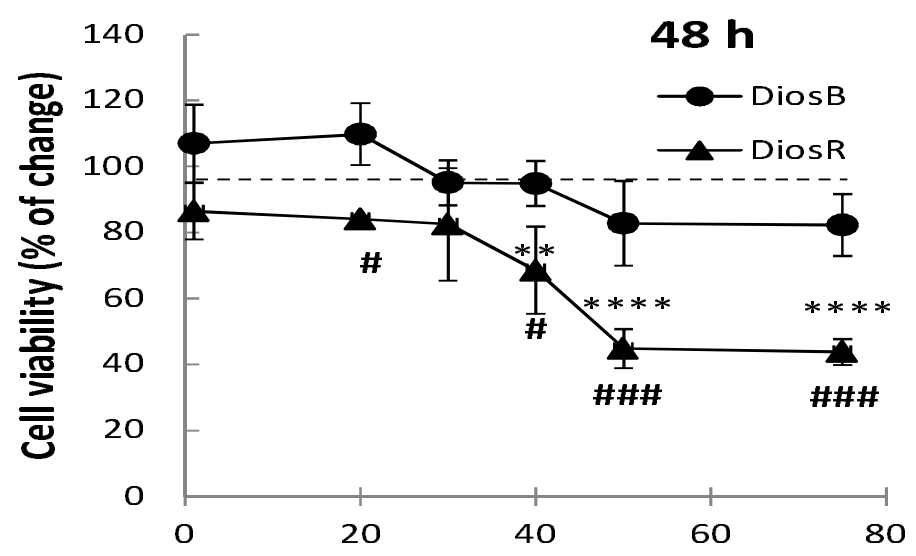

C

D. rotundata $(\mu \mathrm{g} / \mathrm{ml})$

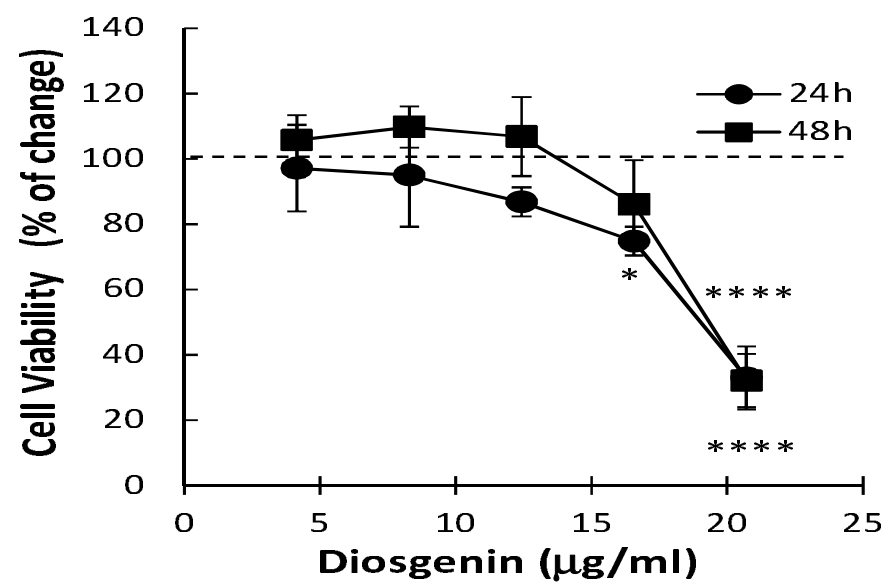

Figure VI: Modulation of MDA-MB231 breast tumor cell viability. Concentration-response curves of $D$. rotundata extracts boiled (DiosB) or raw (DiosR) added at A) $24 \mathrm{~h}, \mathrm{~B}) 48 \mathrm{~h}$ and C) concentration-response curves of Diosgenin. Results were expressed as percentage of change respect to control (cells without treatment, considered as $100 \%$ ). Values are mean \pm S.E.M. of 4 experiments performed in quadruplicate. (\#P $<0.05$; \#\#P $<0.01$; \#\#\#P<0.001; \#\#\#\#P<0.0001 DiosB vs. DiosR. *P<0.05; **P<0.01; ***P<0.001; **** $\mathrm{P}<0.0001$ vs. control). 


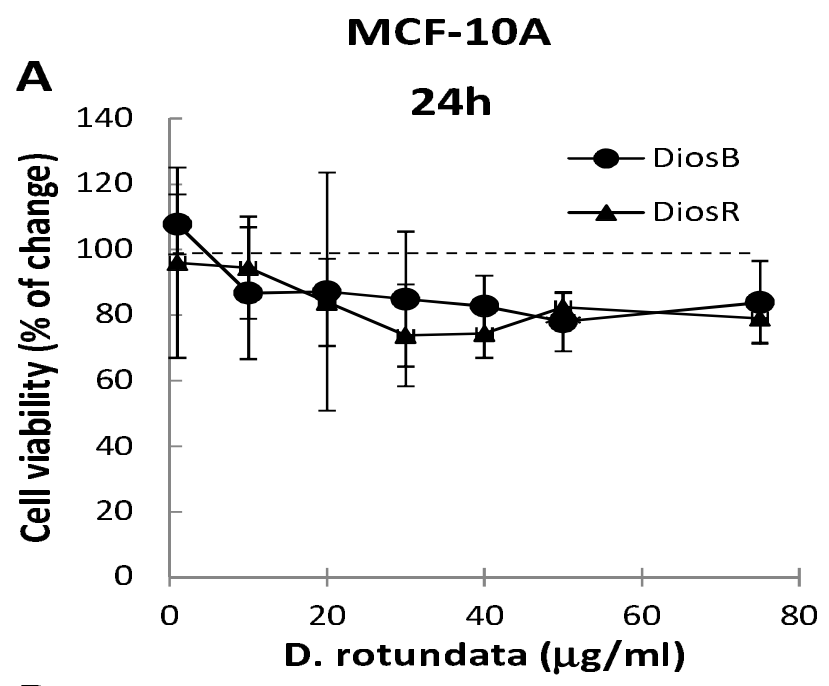

B
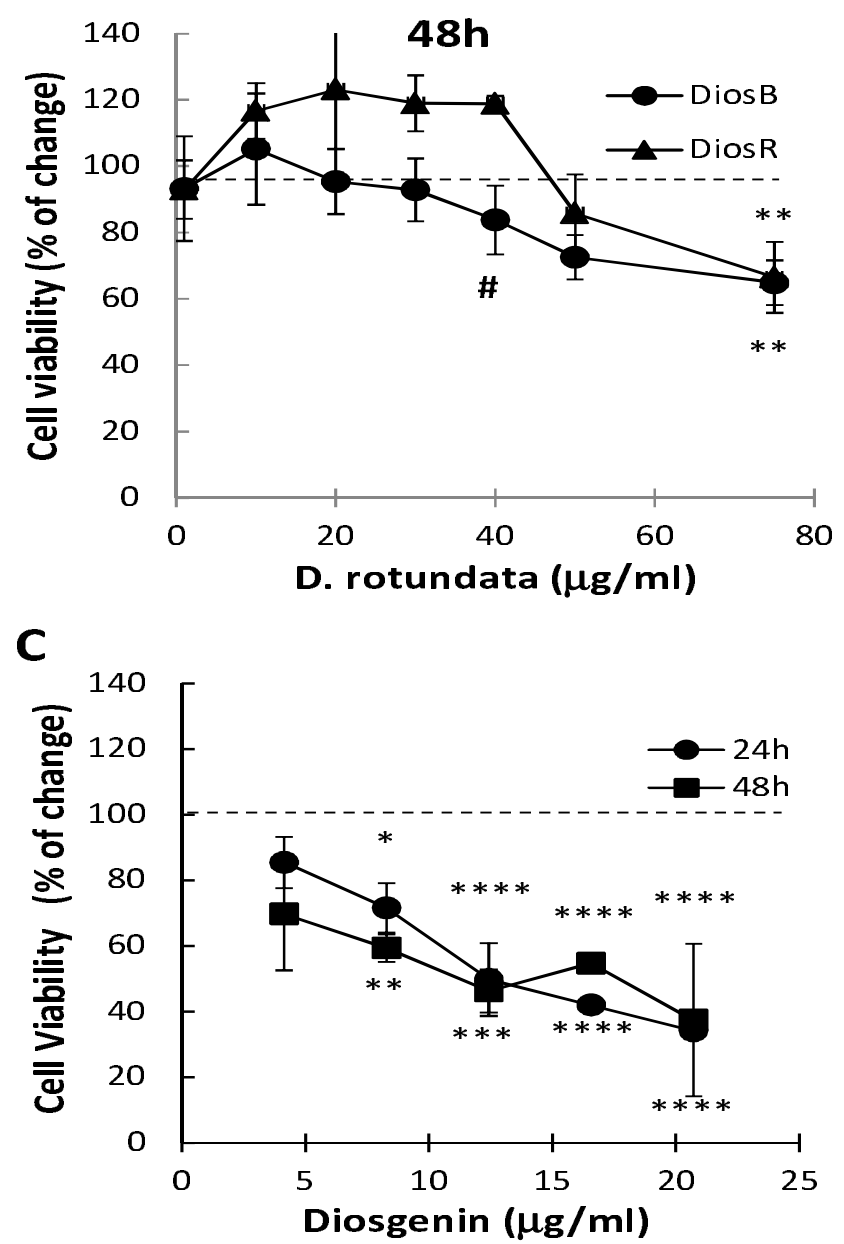

Figure VII: Modulation of MCF-10A non-tumorigenic breast cell viability. Concentration-response curves of $D$. rotundata extracts boiled (DiosB) and raw (DiosR) added during A) $24 \mathrm{~h}, \mathrm{~B}$ ) $48 \mathrm{~h}$ and C) concentration-response curves of Diosgenin added during 24 and 48h. Results were expressed as percentage of change respect to control (cells without treatment considered as $100 \%$ ). Values are mean \pm S.E.M. of 4 experiments performed in quadruplicate. (\#P<0.01 DiosB vs. DiosR. * $\mathrm{P}<0.05$; **P $<0.01 ; * * * \mathrm{P}<0.001 ; * * * * \mathrm{P}<0.0001$ vs. control). 